\title{
GCU
}

Glasgow Caledonian

University

University for the Common Good

\section{Politically connected boards, ownership structure and credit risk: evidence from Chinese commercial banks}

Boateng, Agyenim; Liu, Yang; Brahma, Sanjukta

Published in:

Research in International Business and Finance

DOI:

10.1016/j.ribaf.2018.07.008

Publication date:

2019

Document Version

Author accepted manuscript

Link to publication in ResearchOnline

Citation for published version (Harvard):

Boateng, A, Liu, Y \& Brahma, S 2019, 'Politically connected boards, ownership structure and credit risk:

evidence from Chinese commercial banks', Research in International Business and Finance, vol. 47, pp. 162 173. https://doi.org/10.1016/j.ribaf.2018.07.008

\section{General rights}

Copyright and moral rights for the publications made accessible in the public portal are retained by the authors and/or other copyright owners and it is a condition of accessing publications that users recognise and abide by the legal requirements associated with these rights.

Take down policy

If you believe that this document breaches copyright please view our takedown policy at https://edshare.gcu.ac.uk/id/eprint/5179 for details

of how to contact us. 


\title{
Politically Connected Boards, Ownership Structure and Credit Risk: Evidence from Chinese Commercial Banks
}

\begin{abstract}
This study explores whether the nature of ownership may condition the extent and impact of political connections on credit risk decisions. We find politically connected boards to exert significant influence on credit risk. Further evidence shows that ownership type of the bank moderates the link between politically connected boards and credit risk. Specifically, state owned banks appear to be more susceptible to credit risk while independent directors in private banks tend to be effective monitors. Our findings have important implications for bank stability and provide a means to measure the success of corporate governance reforms carried out in emerging countries over the past two decades.
\end{abstract}

\section{Introduction}

Prior studies examining the effects of political connections have focused predominately on performance of non-financial firms with relatively little attention on financial firms (Ding et al., 2014a; Faccio, 2010; Khwaja and Mian, 2005). These studies document that political connection is a double-edged sword which has both positive and negative impact on firm value (Khwaja and Mian, 2005; Charumilind et al., 2006). On one hand, Fisman (2001); Johnson and Mitton (2003); and Goldman et al. (2009) argue that political connection adds to firm value. They point out that political connections lead to easier access to financial resources such as preferential access to bank loans, lower cost of capital and consequently improved firm performance. On the other hand, others argue that political connection may lead to appointment of managers and directors with lesser qualifications thereby exerting a negative influence on firm value (Boubakri et al., 2012; Leuz and Oberholzer-Gee, 2006; Fan et al., 2007). The above argument is consistent with the grabbing hand theory which contends that state and public firms are exploited to fulfil the interests of politicians by appointing 
government bureaucrats as firm managers and directors under their control (Shleifer and Vishny, 1994; 1998).

Despite the extensive research regarding the effects of political connection on firm value, recent studies such as Nys et al. (2015); Hung et al. (2017) point out that the impact of politically connected banks has received relatively less attention. One exception to prior literature is the study by Hung et al. (2017) which examined the effects of politically connected CEO on bank performance and risk-taking. Studies that examine the effects of politically connected boards and the distinctive ownership structure on bank risk-taking in emerging country context are scant. Yet the nature of shareholders and their different preferences do not only engender conflict of interests but play an important role in the firm's risk choices (Jensen and Meckling, 1976). For example, it may therefore be argued that the nature of ownership (i.e. SOE and private ownership (POE)) may condition the extent and impact of political connection on bank credit decisions. This is because top executives of SOEs are more likely to be politically connected and pursue social objectives of the government due to the pressure from the state authorities compared to the privately owned firms (Hung et al., 2017; Du et al., 2016). Similarly, it is widely acknowledged that, the nature of the board and its composition are critical determinants of a firm's investment decisions and the level of risk-taking within a firm. This argument supports the findings of Dharwadkar et al. (2000), who argue that politically connected directors may not be truly independent and are less effective monitors, especially in the case SOEs.

The above suggests that political connection may exacerbates agency problems. To mitigate conflict of interests, agency theory emphasises a set of corporate governance mechanisms for firm's decision-making and allocation of resources to influence firm risktaking and performance (Jensen and Meckling, 1976; Choi, Park and Hong, 2012). Thus agency theory posits that the dynamic interactions between corporate governance factors are 
important in mitigating conflict of interests engendered by political connections (Jensen and Meckling, 1976; Shi et al., 2018). Yet, corporate governance literature has overlooked the effects of interactions between firm ownership and politically connected corporate boards and their consequent impact on bank risk-taking. This study attempts to fill this gap by investigating the effects of interactions between politically connected CEO (PCCEO), independent directors, ownership type and credit risk of banks in an emerging country context where corporate governance systems appear weak.

The purpose of this study is twofold: (i) to examine the impact of politically connected boards on credit risk; (ii) to investigate whether the nature of firm ownership moderates the effects of politically connected boards on credit risks of Chinese banks. We do so by employing a sample of 88 banks in China over the period of 2003-2014. Drawing on agency theory, we argue that politically connected CEOs may distort efficiency and credit decisions to serve larger political interests, particularly, in the emerging market environment where concentrated ownership is prevalent and corporate governance systems appear weak.

China offers an appropriate setting in which to examine our research questions for the following reasons. First, China, just like other emerging countries, is characterised by weak institutions and underdeveloped corporate governance system (Du and Boateng, 2015; Singh and Gaur, 2009; Dahya et al. 2003). More importantly, the Chinese government actively intervenes in businesses as shareholder and economic manager to pursue social and political goals rather than maximisation of shareholder wealth (Du et al., 2016), thereby magnifying agency problems. Second, political connections are rooted in the institutional context of many emerging countries with far reaching implications on firm strategies, performance and risktaking behaviour (Chin et al., 2013; Grossman et al., 2016). He et al. (2014) support this point and state that building political connections is important in China because Chinese culture values networking in business dealings (Guanxi). Ding et al. (2014a) suggest that the Guanxi 
often goes beyond socialisation to political connection and its complex interlink with business. These considerations led to the choice of China.

Our study finds that politically connected CEO has positive impact on credit risk while the proportion of independent directors exerts a negative and significant influence on credit risk. We also find the joint effect of state ownership (SOE) and PCCEO to increase credit risk. However, the interaction between POE and PCCEO tends to reduce credit risk. Further evidence indicates that independent director of SOEs underperform in terms of their monitoring role compared to POEs. The results are robust after controlling macroeconomic and bank-specific variables.

This study contributes to the literature in the following ways. First, the focus on emerging country context is empirically and theoretical important, as the study allows us to analyse the effects of interactions of the politically connected boards and ownership types on credit risk in an environment where government influence over businesses is pervasive and corporate governance systems appear weak. Given that emerging countries have reformed their corporate governance systems over the past two decades, this study enriches our understanding of the effectiveness of corporate boards in monitoring politically connected banks in relation to their risk-taking decisions therefore contributing to agency theory.

Second, the findings of this study provides new insights into how corporate boards with political ties interact with the nature of firm ownership to influence bank risk-taking behaviour in the allocation of capital in the banking sector. This is significant in that the ability of a country financial system to allocate capital more efficiently with minimum credit risk is an important prerequisite for bank stability and provides a yardstick with which to measure the success of reforms carried out in emerging countries over past two decades.

The rest of the study is structured as follows. The next section discusses the institutional background. This followed by a review of theoretical perspectives of political 
connection, relevant literature and the development of hypotheses of the study in sections 3 and 4. Following that, is an outline of data and methodology employed in this study in section 5. Section 6 discusses the results of the study. The final section summarises the conclusion of the paper.

\section{Institutional Background}

We start this section with a brief review of institutional background of corporate governance reforms in China. Firm governance in China encompasses two-tier system, namely, a board of directors and a supervisory board. Listed companies are required to maintain a board of directors, as well as supervisory board. The board of directors constitute a decision-making unit and the supervisory boards assume the role of monitoring the executive management. Both the board of directors and the supervisory boards are appointed by, and must report to, the shareholders which, in most cases, are the local and central governments. The board of directors is empowered to appoint the CEO and other senior managers, call shareholder meetings, implement the resolutions of shareholder meetings, determine internal management systems and undertake necessary decisions.

Regarding the laws in respect of board of directors, China Securities Regulatory Commission (CSRC) enacted the first Chinese Company Law in 1993, which became effective in 1994 to regulate and monitor management. However, it is important to note that the 1993 Company Law did not provide a guide on the size of the board, the criteria for setting up the board and the provision of independent directors. In 1999, the CSRC modified the 1993 law to highlight the importance of independent directors, nevertheless the law fell short in several respects. For example, the CSRC (1999:p. 2) required overseas-listed corporations to "establish and gradually improve the system for external directors and independent directors" and proposed that "independent directors should hold more than half 
the board seats with at least two independent directors'". These requirements applied only to overseas-listed companies. For domestic listed companies, the concept of independent directors was first introduced in the Guidelines on Company Chapter of Listed Companies (CSRC, 1997) as an optional provision and that a listed company may appoint independent directors if necessary. CSRC (1997) specified persons who may not hold the position of independent director, but remained silent on the minimum number and the duties of independent directors (CSRC, 1997: p.117). A formal, comprehensive guideline on independent directors was enacted in 2001. This code specifies several requirements for listed companies, such as presence of independent directors in the boards, adherence to strict information disclosure norms, and equal status to minority shareholders. This time the law sets out for listed companies target for independent directors composing of, at least, one third of board members by June 30, 2003 (CSRC, 2001).

One distinctive characteristic of firm governance in China is that, independent directors may not be truly independent and often play coordinated and harmonious roles in running the companies along with executive managers, especially for the majority of the listed firms that were previously SOEs (Lin et al., 1998; Huang and Boateng, 2016). Although Chinese firms maintain both a board of directors and a board of supervisors, the supervisory board appears to be ineffective and it is often undermined by its composition and a poorly defined monitoring role with respect to the board of directors and managers (Dahya et al., 2003; Yuan et al., 2009).

\section{Theoretical background}

Studies have shown that political connections have economic consequences for firms (see Dinc, 2005; Faccio et al., 2006). In an attempt to unpack the economic effects of political connections, a number of theoretical perspectives have been put forward to explain the effects 
of political connections. Prominent among the theories include: the grabbing hand theory (Shleifer and Vishny, 1994; 1998); network theory (Field et al., 2013; Yang and Wang, 2011) and agency theory (Jensen and Meckling, 1976). The grabbing hand theory encompasses models of political behaviour that argue that politicians do not maximise social welfare but instead pursue their own self-serving objectives. Thus the theory contends that public firms are exploited by politicians through appointment of government bureaucrats as firm managers and directors to under their control to serve their own interests (Shleifer and Vishny, 1994; 1998). However, scholars have criticised the grabbing hand perspective by point out that the theory is useful in understanding the existing institutions in different countries and the costs and benefits of these institutions in economic growth (Shleifer and Vishny, 1998).

Another channel of political influence on business is the network theory. Under the networks theory or the so-called "network capitalism" firms and the state create a means for directing financial resources to social and political projects which are economically unviable leading to loans default (Boisot and Child, 1996). Research evidence suggests that the networks do not only help access resources for firms but facilitate quicker access to critical information on market conditions (Hoang and Antoncic, 2003; Yang and Wang, 2011; Field et al., 2013). In the context of China, He et al. (2014) point out that building political connections is important in China because Chinese culture values networking in business dealings (Guanxi). Luo et al (2014) therefore indicate that guanxi has become the lifeblood of business conducts and social interactions in Chinese culture. Yang and Wang (2011) support the contention that through a variety of interpersonal and political network relationships, resources can be obtained to increase firm value.

Another central theory that attempts to explain the effects of political connection on firm's decision and performance is the agency theory. Agency theory has become a dominant theory often used to explain the effects of political connection on firm performance and has 
been tested empirically in both developed and developing countries. The overall thrust of agency theory posit that managers are self-serving individuals who pursue their own personal and economic objectives rather than corporate objectives of a firm (Jensen and Meckling, 1976). Agency theory focuses on two main types of agency conflict, that is, traditional principal-agent conflict between shareholders and managers; and principal-principal conflict between controlling and minority shareholders. According to Shi et al. (2018); Boateng and Huang (2017), all the two types of agency conflict are prevalent among Chinese firms. For example, government as a majority shareholder has social objectives and interests compared to other types of shareholders whose aim is maximisation of shareholder wealth. Similarly, managers and politicians maintain connections with firms not to maximise the interests of shareholders, but rather to serve their own personal objectives. Ding et al. (2014b) found executive political connection is positively related to the executive compensation. The above suggests that political connection is indicative of agency problem and detrimental to firm value (Jensen and Meckling, 1976; Aggarwal et al., 2012). However, it is theoretically unclear whether the interaction between the ownership type and politically connected directors as corporate governance mechanism are effective in reducing agency conflicts.

\section{Literature and hypothesis development}

\subsection{Political connections and firm outcomes}

Fisman (2001); and Sapienza (2004) document that political connections have both negative and positive effects on firm strategies and value. At one end of the spectrum, there are a number of studies which argue that political connections lead to favourable treatment in resources allocation and positive economic outcomes for firms. Under this view, scholars such as Goldman et al. (2009); Dinc (2005); Sapienza (2004) point out that politically connected firms tend to have preferential access to government contracts and acquisitions of 
loans at lower interest rates. Shleifer and Vishny (1994); Faccio et al. (2006) further contend that politically connected firms are more likely to receive government funds and liquidity support from the central bank in the event of financial distress. In addition, Hung et al. (2017) document that politically connected firms may face less pressure from legislative compliances such as favourable deadline extensions or less regulatory scrutiny. Overall, these studies provide evidence that political connections have a positive and significant effect on firms' economic outcomes by providing more attractive business opportunities and that political connections serve as insurance mechanism against extreme events for these firms. To Fisman (2001), political connections are a valuable resource for many firms.

In contrast, prior studies have documented that politically connected firms have higher leverage ratios compared to their non-connected counterparts and tend to experience lower risk-adjusted returns (Johnson and Mitton, 2003; Aggarwal et al., 2012). The foregoing suggests that political connections may also lead to risk-taking strategies that destroy firm value and this study attempts to shed lights on the effects of politically connected CEO and independent directors on credit risk.

\subsection{Hypothesis development}

\subsubsection{Politically Connected CEO, Bank Ownership and Credit Risk}

Previous academic work has uncovered an evidence on the relationship between the politically connected boards and bank lending behaviour. Khwaja and Mian (2005) indicate that much of politically connected firms in an environment of poor corporate governance tend to be saddled with a high ratio of non-performing loans (NPLs). Khwaja and Mian (2005) found that state-owned banks provide preferential access to politically connected firms with higher probability of default estimated at 50\%. Researchers such as Li et al. (2006), GarcíaMeca and Sánchez-Ballesta. (2014), and Sapienza (2004) have rendered some support for the 
positive relationship between the politically connected firms and preferential access to loans. Despite the risks and agency costs associated with political connected lending, CEO continues to lend to these firms.

In the context of China, banks with policy-directed loans constitute the largest proportion of the total loans of Chinese banks and grew by 95.3\% in 2009 (Luo and Ying, 2014). Scholars attribute this to the fact that, the Communist Party dominates the political power and controls state institutions and most of the banks in China. Government or its agencies routinely appoint party members and government officials to the board and executive management of SOEs including banks (Dong et al., 2014; Fan et al., 2007). Su, Xu and Phan (2008) point out that as state representatives, directors and firm leadership have a duty to uphold government policies aimed at reducing unemployment, improving social and political stability rather than maximisation of shareholder wealth. Credit standards and lending behaviours may conform to the political dictates and demands as noted by Luo and Ying (2014) and Li et al. (2008), resulting in principal-principal conflict between controlling and minority shareholders. Firth et al. (2008), Li et al. (2008) indicate that appointment of politically connected CEOs and directors are not limited to SOEs and POEs frequently appoint former government officials as CEOs. However, given the pervasive influence of Chinese government over businesses, we expect strategic direction and managerial decisions on lending policies and loans quality of SOEs to be more prone to political participation and pressures compared to POEs. In the light of the above argument, we hypothesise that:

H1: Ownership type of the bank will moderate the link between the politically connected CEO and credit risk in such a way that state ownership (private ownership) will positively (negatively) related to credit risk. 


\subsubsection{Board Independence, Bank Ownership and Credit Risk}

Over the past decade, there has been intense academic and regulatory interest on how to mitigate bank-risk taking. This is because excessive risk-taking by banks jeopardises the safety and soundness of individual institutions and the stability of the entire financial sector. Stulz (2015) argues that good corporate governance plays an important role in helping banks to pursue optimal level of risk to enable managers maximise firm value. The board of directors are widely seen as an important prerequisite for an effective internal governance framework (Fama and Jensen, 1983). Thus the board has the responsibility for risk management and set the tone for a bank's risk-taking culture at the top and evaluate whether the current and future risk is in line with risk tolerance level of the bank (Hagendorff and Vallascas, 2011). Drawing on agency theory, Byrd and Hickman (1992) contend that the monitoring role of the board is facilitated by a board whose composition reflects a greater proportion of outside independent directors since such composition could represent a more effective way in monitoring and controlling managerial actions.

In the context of China, the distinctive feature of boards is the presence of politically connected directors. As pointed out earlier, the prevalence of government directors with political connections provides a means for these directors to promote and execute government policies and agendas despite the risks associated with such policies to firms ( $\mathrm{Su}, \mathrm{Xu}$ and Phan, 2008). It is pertinent to note that, POEs often invite politically connected government officials with rich human and social capital to sit on their boards (Chen, 2015). According to Hillman (2005), the appointment of politically connected government officials to POEs is done to reduce uncertainty by connecting these firms to influential politicians to help manage their dependence on government. Consequently, the monitoring role of independent directors may not be effective and are influenced by factors such as their social and political ties (Zhu 
and Yoshikawa, 2015). Strong ties with government may mean less focus on shareholder maximisation and higher risk taking. Ding et al. (2014b) found state ownership to weaken board independence. In this study, we argue that the type of ownership of the bank may affect the monitoring role and risk-taking behaviour due to the divergence of goals between SOEs and POEs and the relative bargaining power of the state agency and private investors in bank decision making (see Sun and Tong, 2003). Thus we hypothesise that:

H2: Ownership type of the bank will moderate the link between the politically connected independent director monitoring role and credit risk in such a way that state ownership (private ownership) will be positively (negatively) related to credit risk.

\subsubsection{Control variables}

Following Garcia-Herrero et al. (2009), we control the macroeconomic and bank-specific variables, namely, CEO total compensation (CEO_TC); growth GDP (GDPR); inflation (INFR); unemployment rate (UNEMP); bank size (SIZE); and leverage (LEVR). Research evidence suggests that macroeconomic and bank-specific variables are likely to affect repayment behaviours of borrowers and credit decisions. Gross Domestic Product (GDP) reflects the demand and the size of the economy and affects the bank risk-taking behaviour and performance (Fries and Taci, 2005). Regarding the inflation, Dinc (2005) indicate that inflation has effect on credit markets. For example, rising inflation rate could increase default rates because it negatively affects real incomes of borrowers (Ghosh, 2015). Rising unemployment increases default risk in the banking industry and reduce bank profitability (Fu and Heffernan, 2009). Higher unemployment rates tend to produce more non-performing loans and loan loss reserves.

Prior studies suggest that bank size affects bank profitability (e.g., Luo and Ying, 2014; Leuz and Oberholzer-Gee, 2006). It is argued that large banks may have the capacity to extend loans to a large segment of the population thereby increasing its loan portfolio and default 
rates. Sapienza (2004) contends that bank size may also influence the ability to take and absorb risk. According to agency theory, a positive relationship exists between CEO compensation and risk (Jensen and Murphy, 1990). Compensation increases the incentive of bank CEO's to take more risks. As a result, total compensation is positively related to bank risk. We therefore control the total compensation. We also include ownership type dummies, that is government owned and privately owned to account for the effect ownership effect in the regression estimations.

\section{Data and Methodology}

\subsection{Data source and sample selection}

The data is derived from the records of Chinese Stock Market and Accounting Research Database (CSMAR), China Statistical Yearbook published by the National Bureau of Statistics of China and the Bankscope database provided by Fitch-IBCA (International Bank Credit Analysis Ltd). For inclusion in the final sample, the following restrictions were imposed, Only commericial banks, that is, city commercial banks, rural commercial banks and foreign banks are selected. Policy banks, cooperative banks and investment banks are excluded because they may have different objectives rather than profitability. Banks with missing data such as non-performing loans and other relevant data are excluded. The imposition of these restrictions led to the final usable sample of 88 banks and covers the period of 2003-2014. Table 1 reports the details of the sample selection.

[Insert Table 1 here] 


\subsection{Econometric Model}

In order to estimate the effects of independent variables on the dependent variables, we employ the System Generalised Method of Moments (SGMM) model to carry out our analysis. Prior studies on internal governance indicate that research in this area should consider that governance variables are endogenous (Boone et al., 2007). The regression of board characteristics on credit risk is likely to suffer from three endogeneity problems such as omitted variables, reverse causality and measurement error. Wintoki et al. (2012) provide strong evidence that the instruments associated with a dynamic GMM approach are valid and more appropriate for corporate governance research. To address the problem of endogeneity, we employ the two-step Arellano and Bover (1995)/Blundell and Bond (1998) dynamic panel-data system estimator with Windmeijer (2005) bias-corrected robust standard errors in all models. We test for second order serial correlations AR(2) and Sargan test of overidentifying restrictions for validity of our model and the GMM instruments.

Our basic econometric model is specified as follows:

CRisk $_{i t}=\alpha_{0}+\beta_{1}$ PCCEO $_{i t}+\beta_{2} B_{-} I N D_{i t}+\beta_{k}$ INTERACTION $_{i t}+\sum_{i=1}^{n} \beta_{i}$ CONTROLS $_{i t}+\gamma_{i}+\varepsilon_{i t}$ (1)

CRisk represents non-performing loan ratio (NPLR) and loan loss provision ratio (LLPR). The set of explanatory variables: PCCEO and B_IND represent the politically connected CEO and board independence respectively. INTERACTION refers to the interaction variables between politically connected board and ownership type, including PCCEO*SOE, PCCEO*POE; and $B \_I N D * S O E, \quad B \_I N D * P O E$, The control variables (Controls) include: growth gross domestic produect rate (GDP), unemployment rate (UNEMP), inflation rate (INFR), bank size (SIZE) and bank leverage ratio (LEVR), and CEO total compensation (CEO_TC). . 


\subsection{Measurement of Variables}

Table 2 describes how the dependent and independent variables of our study are measured.

\section{Dependent Variables}

We employ two different risk measures as dependent variables and proxies for credit risk, namely, Non-Performing Loan Ratio (NPLR) and Loan Loss Provision Ratio (LLPR). The volume of NPL to total equity to account for loan portfolio risk ${ }^{1}$ (Ghosh, 2015). Following Elnahass et al. (2014), we estimate the LLPR as Loan Loss Provision (LLP) divided by Net Interest Revenue (NIR).

(Insert Table 2 here please)

\subsubsection{Summary Statistics}

Table 3 presents the descriptive statistics for all variables used in this study. The mean value of NPLR is about $2.7897 \%$ which is comparable with that of Dong et al (2014) who reported a mean value of $2.62 \%$ for the period from 2003-2011. Regarding the PCCEO, the mean value is about $93.9 \%$, indicating that PCCEO is the pervasive in the banking industry in China. $24.12 \%$ of the board of directors are independent directors indicating that despite corporate governance reforms, the proportion of independent directors of the sample banks appears relatively low compared to that found in the UK and other advanced market economies. The mean value of the total compensation for CEOs is about 4.75 .

\footnotetext{
${ }^{1}$ We also include the volume of nonperforming loans to total equity for robustness check.
} 


\section{(Insert Table 3 here)}

\section{Correlation Matrix}

Table 4 reports the correlation matrix of dependent and independent variables. All the correlation coeficients are fairly low indicating that multicollinearity is not an issue. Further test using variable inflation factor (VIF) procedure suggests that all the correlation coefficients are well below 0.70 threshold thereby confirming that multicollinearity is not to be a problem in this study.

(Insert

Table

4

here) 


\section{Regression Results and Discussion}

\subsection{Baseline Results}

Table 5 presents the baseline results of the SGMM estimation based on two dependent variables, namely, NPLR and LLPR. As shown in columns 1 and 2, the coefficient for the politically connected CEO is positive and significant at $1 \%$ level indicating that PCCEOs exert positive and significant influence on credit risk in China. The results suggest that PCCEOs provide a vehicle for political interference in capital allocation to favoured projects with high social returns which involve high risk leading to increase in credit risks. The findings may be explained by the extent of Chinese government and its agencies involvement in the appointment of CEOs to these banks.. The results appear consistent with the findings of Engelberg et al. (2012) who found that firms including private ones actively look for various means of building business-state networks. These connections make the CEOs more prone to upholding government policies aimed at reducing unemployment, improving social and political stability. Consequently, credit standards may be lowered by the firms in the network and lending behaviours may therefore conform to the political dictates and demands as noted by Luo and Ying (2014) and Li et al. (2008) thereby increasing default rates.

Our results in Table 5 document that the proportion of independent directors on the board have a negative and significant influence on credit risk suggesting that the proportion of independent directors tend to reduce credit risk. The results suggest that board composition which include outside independent directors tend to facilitate effective monitoring and the control of credit risk. The results appear consistent with the findings of Beltratti and Stulz (2012), who found the proportion of independent directors to be negatively associated with bank loan quality and credit risk. However, the findings are at variance with the conclusions drawn in the study by Dharwadkar et al. (2000) which indicates that independent directors in 
emerging economies are ineffective, lack resources and are likely to carry out advisory role rather than the oversight role.

Regarding control variables, our regression results indicate that the coefficients for the CEO total compensation in the two models are positive and highly significant at the $1 \%$ level suggesting that CEO remuneration affects the credit risk of the Chinese banks. The results corroborate the findings of prior studies (e.g., Ghosh, 2015). We find GDP and unemployment to have positive and significant effect on credit risk while inflation rate, bank size, leverage and ownership type are negatively related to credit risk.

(Inset Table 5 here)

\subsection{Politically connected boards, ownership Type and Credit Risk}

In Table 6, we analyse the effects of interactions of ownership type and politically connected CEO and independent directors on credit risk in Models 1-4. We therefore incorporate interactive variables for ownership measures and PCCEO and proportion of independent director (B_IND) in our regression. Models 1 and 3 of Table 6 report the interaction between ownership type and PCCEO. We find positive and significant coefficients for the interactions: PCCEO*SOE $(\beta=8.206 ; p<.01)$ in model 1 and a negative and significant effect on credit risk PCCEO*POE: $(\beta=-4.271, \mathrm{p}<0.01)$. Overall, the findings in Table 6 suggest that government ownership are more prone to higher credit risk compared to private ownership. The findings may be explained by the government ownership and control of SOE through appointment of CEOs thereby rendering managerial decisions on lending policies of SOEs to be more prone to political participation and pressures compared to POEs. Thus government 
ownership and control exacerbate agency problems.

In the case of interaction between the ownership type and proportion of independent directors, we find that the interaction between independent directors and SOE appears positive but insignificant. However, the interaction between private ownership and independent directors is negative and significant. Hypothesis 2 is supported. The findings suggest independent directors of POEs tend to reduce credit risk compared to that of SOEs. The results may be explained by the nature and differences of resources and capabilities available to the private banks relative to state owned banks. For example, unlike state banks whose directors may derive their positions through political connections, independent directors in privately owned banks (although politically connected), may be appointed on the basis of their qualifications, competence, experience and capacity to perform the monitoring role associated with the position thereby ameliorating credit risks in these banks.

(Insert Table 6 here)

\subsection{Robustness Checks}

To check the robustness of our main results, we employ additional specification to rule out alternative explanations. To ascertain whether our main results are driven by the effects of 2008 financial crisis, we exclude the data relating to the period of 2007/08 global financial crisis. The results reported in Table 7 remain unchanged suggesting the robustness of our main findings.

(Insert Table 7 here) 


\section{Conclusions}

This study investigates the effects of politically connected boards and further investigate the effects of interaction between politically connected board and ownership type on credit risk of Chinese banks over the period of 2003-2014. Despite a number of studies exploring the influence of politically connected boards on firm's performance, virtually, no study has examined corporate risk-taking decisions as a function of board political orientation and connection in emerging market environment where institutions and corporate governance systems appear weak. Using a sample of 88 Chinese banks, we find politically connected boards to exert significant influence on credit risk. Specifically, our evidence shows that state ownership positively moderates the link between politically connected CEO and credit risk while private ownership negatively moderates credit risk. Specifically, we find state owned banks to be more susceptible to credit risk while independent directors in private banks tend to be effective monitors. However, independent directors exert a negative and significant influence on credit risk. Thus the joint effect of PCCEO and SOE increases credit risk while the interaction between PCCEO and POE tends to reduce credit risk. Regarding the interactions between independent directors and bank ownership, we also find the joint effect of independent directors and POE to be negative and significant while the interaction between independent and SOE appears to be positive but insignificant. Our findings indicate that independent directors of SOEs underperform in terms of their monitoring role compared to POEs. The results are robust after controlling macroeconomic and bank-specific variables.

The finding that PCCEO exerts significant influence on credit risk suggests that the governments in developing countries play a bigger role in the allocation of financial resources through its appointees thereby distorting the credit allocation and increasing the probability of credit default. Further evidence based on the interactions of ownership type and political connected board variables indicate that SOEs are more prone to higher credit risk 
compared to private ownership. The findings imply that the banking sector reforms carried out in China have not curbed the pervasive influence of the state and its agencies in credit allocation which often result in non-performing loans. Thus our results suggest that severe agency problems in Chinese banking system persists and we urge further reforms. Specifically, we suggest that Chinese government should pay more attention to the nature and scope of financial sector and enterprise reforms carried out so far and reduce state involvement in the operational activities of commercial banks in China to enhance efficient allocation of formal financing and its retrieval. Another important issue raised by the results of this study is the appointment of CEOs by the government and its agencies. The appointment of politically connected CEOs to top management positions may result in the use of management power to implement strategic initiatives and credit policies favourable to government, increase default risks among Chinese banks with far-reaching implications for operational viability and long-term stability of Chinese banking system and its economy. We suggest that Chinese government should take steps to reform the appointment of top level management, particularly of the SOEs. In particularly, more emphasis should be place of qualification, experience and track record in the field and incentivise these top level managers based on performance in key areas such as loans quality and reduction of non-performing loans.

The negative and significant impact of the proportion of independent directors on credit risk suggests that oversight role of boards in emerging countries leads to substantive improvements in risk management and informed risk-taking as pointed out by Ittner and Keusch (2015). The implication here is that board composition affect organisational outcomes and strategies. Consequently, the present corporate governance code where listed companies are required to appoint at least one-third of independent directors on their boards 
should be raised to at least half in line with what is found in advanced countries such as UK and U.S.

Despite the contribution of this study on how corporate political ties affect a firm's risktaking behaviour in the allocation of capital in formal financing sector, more studies appear warranted. Future studies should investigate the impact of politically connected CEO and compensation on overall risk-taking behaviour of emerging market banks using cross-country data.

\section{References:}

Aggarwal, R.K., Meschke, F., \& Wang T. Y. (2012). Corporate political donations: Investment or agency? Business and Politics, 14, 1, 1649-3569.

Arellano M, \& Bover O. (1995). Another look at the instrumental variable estimation of error-components models, Journal of Econometrics, 68, 1, 29-51.

Beltratti, A, \& Stulz R. M. 2012. The credit crisis around the globe: Why did some banks perform better during the credit crisis?. Journal of Financial Economic, 105, 1, 1-17.

Berger, A., Klapper, L., \& Turk-Ariss R. (2009). Bank competition and financial stability, Journal of Financial Services Research, 35, 2, 99-118.

Boateng, A. \& Huang, W. (2017). Multiple large shareholders, excess leverage and tunnelling: Evidence from emerging market, Corporate Governance: An International Review, 25, 1: 5874.

Boubakri, N., Guedhami, O., Mishra, D., \& Staffar, W. (2012). Political connections and the cost of capital, Journal of Corporate Finance, 18, 3, 541-559.

Boisot M, \& Child J. (1996). From fiefs to clans and network capitalism: Explaining China's emerging economic order, Administrative Science Quarterly, 41, 4, 600-628.

Boone, A. L., Field, L. C, Karpoff, J.M., \& Raheja C. G (2007). The determinants of corporate board size and composition: An empirical analysis. Journal of Financial Economics, 85, 1, 66-101.

Blundell, R., \& Bond, S. (1998). Initial conditions and moment restrictions in dynamic panel data models, Journal of Econometrics, 87, 1, 115-143.

Byrd, J, \& Hickman, K. (1992). Do outside directors monitor managers? evidence from tender offer bids. Journal of Financial Economics, 32, 2, 195-221. 
Charumilind, C., Kali, R. \& Wiwattanakantang, Y., (2006). Connected lending: Thailand before the financial crisis. The Journal of Business, 79, 1,181-218.

Chen, T. (2015). Institutions, board structure, and corporate performance: evidence from Chinese firms, Journal of Corporate Finance, 32, 217-237

Chin, M. K, Hambrick, D. C, \& Trevino L.K. (2013). Political ideologies of CEOs: the influence of executives' values on corporate social responsibility. Administrative Science Quarterly, 58, 2, 197-232.

China Securities Regulatory Commission (CSRC) 2001. Guidelines for introducing outside directors to the board of directors of listed companies. CSRC: Beijing, China.

[Online].Available

from:http://www.csrc.gov.cn/pub/csrc_en/newsfacts/release/200708/t20070810_69191.html [Accessed on 08 Auguest 2016]

China Securities Regulatory Commission (CSRC) 1999. Standards on the content and formats of information disclosure by public issuing companies. No. 2: Annual Reports. Beijing: CSRC.

China Securities Regulatory Commission (CSRC). 2001. Guanyu zai shangshi gongsi jianli duli dongshi zhidu de zhidao yijian (Guidance opinion on the establishment of an independent director system in listed companies, Beijing: CSRC.

Choi, S.B., Park, B., \& Hong, P. (2012). Does ownership structure matter for firm technological innovation performance? The case of Korean firms, Corporate Governance: An International Review, 20, 3, 267-288.

Dahya J, Karbhari Y, Xiao J, \& Yang M. (2003). The usefulness of the supervisory board report in China. Corporate governance: An international review, 11, 4, 308-321.

Dharwadkar R, George G, \& Brandes P. (2000). Privatization in emerging economies: An agency theory perspective, Academy of Management Review, Vol. 25, No. 3, pp.650-69.

Dinc S (2005). Politicians and banks: Political influences on government-owned banks in emerging markets. Journal of Financial Economics, 77, 2, 453-479.

Ding S, Jia C, Wilson C, \& Wu Z. (2014a). Political connections and agency conflicts: the roles of owner and manager political influence on executive compensation. Review of Quantitative Finance and Accounting, 45, 2, 407-434.

Ding, S., Jia, C., Wu, Z. \& Zhang, X. (2014b). Executive political connections and firm performance: comparative evidence from privately-controlled and state-owned enterprises, International Review of Financial Analysis, 36, 153-167.

Dong, Y, Meng, C, Firth, M, \& Hou, W. (2014). Ownership structure and risk-taking: Comparative evidence from private and state-controlled banks in China. International Review of Financial Analysis 36,120-130.

Du, M \& Boateng, A. (2015). State ownership, institutional effects and value creation in 
cross-border mergers \& acquisitions by Chinese firms, International Business Review, 24, 3 : 430-442.

Du, M, Boateng A, \& Newton D. (2016). The impact of state ownership, formal institutions and resource seeking on acquirers' returns of Chinese M\&A. Review of Quantitative Finance \& Accounting, 47.1, 159-178.

Elnahass, M, Izzeldin, M, \& Abdelsalam O. (2014). Loan loss provisions, bank valuations and discretion: A comparative study between conventional and Islamic banks, Journal of Economic Behavior \& Organization, Special Issue, 103, S160-S173

Engelberg, J, Gao P, Parsons CA. (2012). Friends with money, Journal of Financial Economics, 103, 1, 169-188.

Faccio, M (2010). Differences between politically connected and non-connected firms: a cross-country analysis. Financial Management, 39, 3, 905-927.

Faccio, M., Masulis, R, \& McConnel J. (2006). Political connections and corporate bailouts, Journal of Finance, 61, 6, 2597-2635.

Fama, E, \& Jensen, M.C. (1983). Separation of ownership and control. Journal of Law and Economics, Vol, 26, No. 2, pp.301-326.

Fan J. P. H, Wong TJ, Zhang T. (2007). Politically connected CEOs, corporate governance, and post-IPO performance of China's newly partially privatized firms, Journal of Financial Economics, Vol. 84, No. 2, pp.330-357.

Field, L., Lowry, M., \& Mkrtchyan, A. (2013). Are busy board detrimental? Journal of Financial Economics, 109, 1, 63-82.

Firth, M., Fung, P.M. \& Rui, O. M. (2008). Ownership, governance mechanisms, and agency costs in China's listed firms. Journal of Asset Management, 9, 2, 90-101.

Fisman, R. (2001). Estimating the value of political connections. American Economic Review, 91, 4, 1095-1102.

Fries, S., \& Taci, A. (2005). Cost efficiency of banks in transition: Evidence from 289 banks in 15 post-communist countries. Journal of Banking \& Finance 2 29, 1, 55-81.

$\mathrm{Fu}, \mathrm{X}, \&$ Heffernan, S. (2009). The effects of reform on China's bank structure and performance. Journal of Banking \& Finance, 33, 1, 39-52.

García-Meca, E., Sa'nchez-Ballesta, J. P (2014). Politicization, banking experience and risk in savings banks. European Journal of Law and Economics, 38, 3, 535-553.

García-Herrero, A, Gavilá, S., Santabárbara, D. (2009). What explains the low profitability of Chinese banks? Journal of Banking and Finance, 33, 11, 2080-2092. 
Ghosh A. (2015). Banking-industry specific and regional economic determinants of nonperforming loans: Evidence from US states. Journal of Financial Stability, 20, 93-104.

Goldman, E, Rocholl, J, \& So, J. (2009). Do politically connected boards of directors affect firm value? Review of Financial Studies, 22, 6, 2331-2360.

Grossman, A., Okhmatovskiy, I., \& Wright, M.. (2016). State control and corporate governance in transition economies: 25 year on from 1989, Corporate Governance: An International Review, 24, 3, 200-221.

Hagendorff, J., \& Vallascas, F. (2011). CEO pay incentives and risk-taking: evidence from bank acquisitions. Journal of Corporate Finance, 17, 1078-1095.

He, L, Wan, H, \& Zhou, X. (2014). How are political connections valued in China? evidence from market reaction to CEO succession, International Review of Financial Analysis, 36, $141-152$.

Hillman, A. (2005). Politicians on the board of directors: do connections affect the bottom line? Journal of Management, 31, 3, 464-481.

Hoang, H. \& Antoncic, B. (2003). Network-based research in entrepeurship: A critical review, Journal of Business Venturing, 18, 2, 165-187.

Huang, W., \& Boateng, A.. (2016). Executive shareholding, compensation and analyst forecast of Chinese firms, Applied Economics, 49, 15, pp. 159-1472

Hung, C-H D., Jiang, Y., Liu, H., Tu, H. \& Wang, S. (2017). Bank political connections and performance in China, Journal of Financial Stability, 32, 57-69.

Ittner, C. \& Keuch, T. (2015). The influence of board of directors' risk oversight on risk management maturity and firm risk-taking, AAA Meeting, Available at papers.ssm.com.

Jensen, M, \& Meckling, W. (1976). The theory of the firm: managerial behaviour, agency costs, and ownership structure, Journal of Financial Economics, 3, 4, 305-360.

Jensen, M. C., \& Murphy, K. J. (1990). Performance pay and top-management incentives. Journal of Political Economy, 98, 2, 225-264.

Johnson, S, \& Mitton, T. (2003). Cronyism and capital controls: evidence from Malaysia. Journal of Financial Economics, 67, 2, 351-382

Khwaja, A, \& Mian, A. (2005). Do lenders favor politically connected firms? rent provision in an emerging financial market. Quarterly Journal of Economics, 120, 4, 1371-1411.

Leuz, C., \& Oberholzer-Gee, F. (2006). Political relationships, global financing, and corporate transparency: evidence from Indonesia. Journal of Financial Economics, 81, 2, 411-439. 
Li, H., Meng, L., Wang, Q. \& Zhou, L. (2008). Political connections, financing and firm performance: evidence from Chinese private firms. Journal of Development Economics, 87, 2, 283-299.

Lin, J. Y., Cai, F, \& Li Z. (1998). Competition, policy burdens, and state-owned enterprise reform, American Economic Review, 88, 422-427.

Lin, K.J., Tan, J., Zhao, L. \& Karim, K. (2015). In the name of charity: political connections and strategic corporate social responsibility in a transition economy. Journal of Corporate Finance, 32, 327-346.

Luo, Y., Huang, Y. and Wang, S.L. (2012). Guanxi and organisational performance: A metaanalysis, Management and Organisational Review, 8, 139-172.

Luo, D., \& Ying, Q. (2014). Political connections and bank lines of credit. Emerging Markets Finance \& Trade, 50, 3, 5-21.

Nguyen, V. H. T., \& Boateng, A. (2015). An analysis of involuntary excess reserves, monetary policy and risk-taking behaviour of Chinese banks, International Review of Financial Analysis, 37, 63-72

Nys, E., Tarazi, A., \& Trinugroho, I. (2015). Political connections, bank deposits, formal deposit insurance, Journal of Financial Stability, 19, 83-104.

Sapienza P. (2004). The effects of government ownership on bank lending. Journal of Financial Economics, 72, 2, 357-384.

Shi, H., Xu, H., \& Zhang, X. (2018). Do politically connected independent directors create or destroy value? Journal of Business Research, 83, 82-96.

Shleifer A., \& Vishny R. (1989). Managerial entrenchment, Journal of Financial Economics, Vol. 25, No.1, pp. 123-139.

Shleifer, A., \& Vishny, R. W. (1994). Politicians and firms, Quarterly Jornal of of Economics, 109, 4, 995-1025.

Shleifer, A., \& Vishny, R. W. (1998). The grabbing hand: government pathologies and their cures, Harvard University Press, Cambridge, Massachussetts.

Singh, D. A, Gaur, A. S. (2009). Business group affiliation, firm governance and firm performance: evidence from China and India. Corporate Governance: An International Review, 17, 4, 411-425.

Stulz, R. M. (2015). Risk-taking and risk management by banks. Journal of Applied Corporate Finance, 27, 1, 8-18.

Su, Y., Xu, D, \& Phan, P. H. (2008). Principal-principal conflict in the governance of the Chinese public corporations. Management and Organization Review, 4, 17-38. 
Sun, Q, Tong \& W.H. S. (2003). China share issue privatization: the extent of its success, Journal of Financial Economics, 70, 2, 183-222

Windmeijer F. (2005). A finite sample correction for the variance of linear efficient two-step GMM estimators, Journal of Econometrics, 126,1, 25-51.

Wintoki, M, Linck, J, \& Netter, J. (2012). Endogeneity and the dynamics of internal corporate governance, Journal of Financial Economics, 105, 3, 581-606.

Wu, W., Wu, C., Zhou, C. and Wu, J., (2012). Political connections, tax benefits and firm performance: evidence from China. Journal of Accounting and Public policy, 31,3, 277-300

Yang, Z., and Wang, C.L. (2011). Guanxi as a governance mechanism in business markets: its characteristics, relevant theories, and future research directions, Iindustrial Marketing Management, 40, 492-495.

Yuan, R., Xiao, J. Z, Milonas, N, \& Zou, J. H. (2009). The Role of financial institutions in the corporate governance of listed Chinese companies. British Journal of Management, 20, 4, $562-580$.

Zhu, H., \& Yoshikawa, T. (2015). Contingent value of director identification: The role of government directors in monitoring and resource provision in an emerging economy. Strategic Management Journal, 37,8, 1787-1807. 